\title{
Correction to: Small extracellular vesicles encapsulating CCL2 from activated astrocytes induce microglial activation and neuronal apoptosis after traumatic spinal cord injury
}

Yuluo Rong ${ }^{\dagger}$, Chengyue $\mathrm{Ji}^{\dagger}$, Zhuanghui Wang ${ }^{\dagger}$, Xuhui $\mathrm{Ge}^{\dagger}$, Jiaxing Wang, Wu Ye, Pengyu Tang, Dongdong Jiang, Jin Fan, Guoyong Yin, Wei Liu* and Weihua Cai

\section{Correction to: J Neuroinflamm (2021) 18:196}

https://doi.org/10.1186/s12974-021-02268-y

Following publication of the original article [1], the author noticed that Figs. 6 and 7 of the published version of this article were incorrectly uploaded. Presented here are the corrected Figs. 6 and 7 .

Published online: 07 December 2021

The original article can be found online at https://doi.org/10.1186/s12974021-02268-y.

*Correspondence: liuweiorth@njmu.edu.cn; caiwhspine@sina.com

†Yuluo Rong, Chengyue Ji, Zhuanghui Wang and Xuhui Ge contributed equally to this work

Department of Orthopaedics, First Affiliated Hospital of Nanjing Medical

University, Nanjing 210029, Jiangsu, China

(c) The Author(s) 2021. Open Access This article is licensed under a Creative Commons Attribution 4.0 International License, which permits use, sharing, adaptation, distribution and reproduction in any medium or format, as long as you give appropriate credit to the original author(s) and the source, provide a link to the Creative Commons licence, and indicate if changes were made. The images or other third party material in this article are included in the article's Creative Commons licence, unless indicated otherwise in a credit line to the material. If material is not included in the article's Creative Commons licence and your intended use is not permitted by statutory regulation or exceeds the permitted use, you will need to obtain permission directly from the copyright holder. To view a copy of this licence, visit http://creativecommons.org/licenses/by/4.0/. The Creative Commons Public Domain Dedication waiver (http://creativecommons.org/publicdomain/zero/1.0/) applies to the data made available in this article, unless otherwise stated in a credit line to the data. 
A

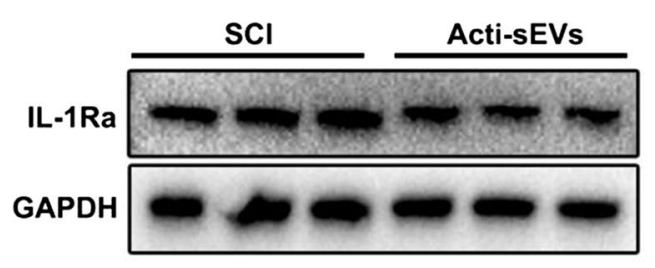

C
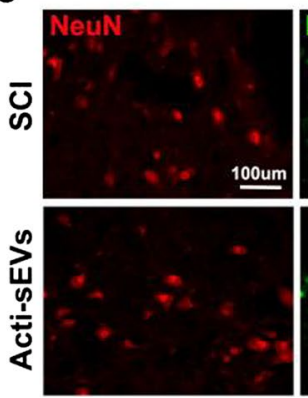

B
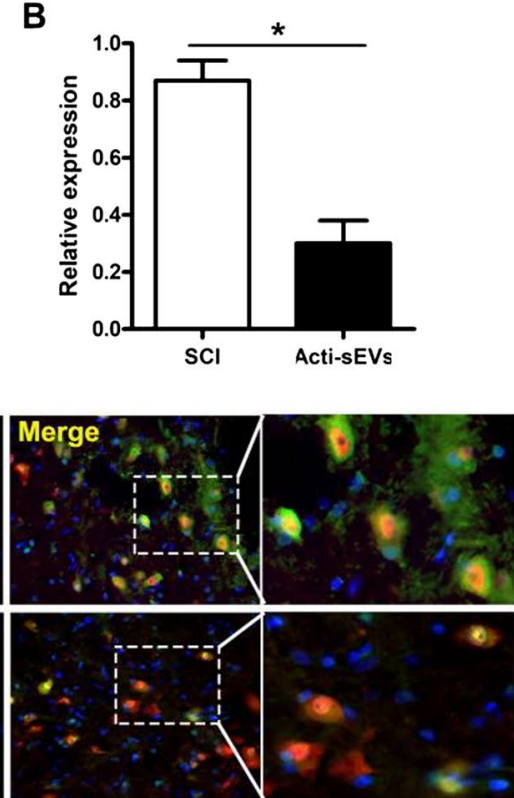

Fig. 6 CCL2-induced microglial activation may aggravate neuronal apoptosis. A, B Western blotting detection of IL-1 Ra protein expression in spinal cord tissue. C Immunofluorescence detection of IL-1 Ra protein expression in neuronal cells
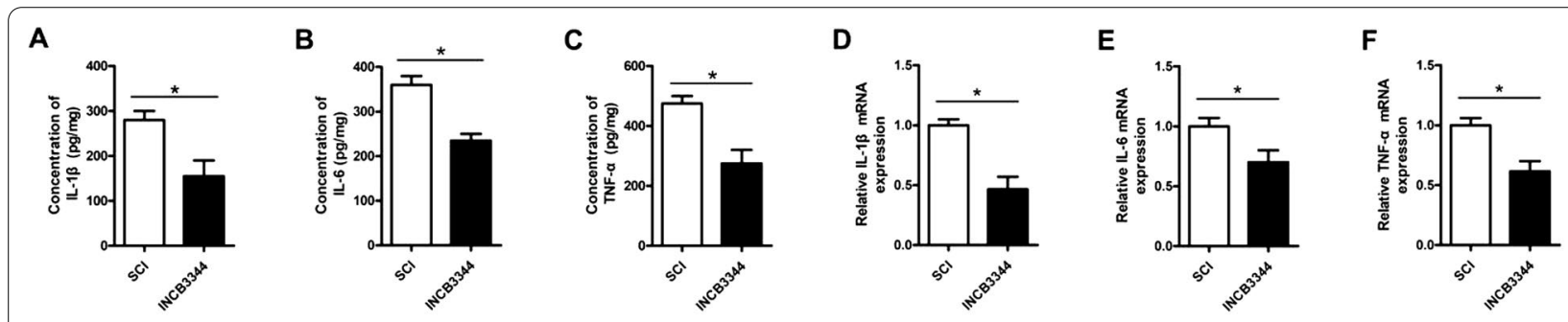

$\mathbf{G}$

H


$\mathbf{L}$

M

Fig. 7 The CCR2 antagonist INCB3344 decreases microglial activation and neuronal apoptosis after SCI. A-H ELISA, qRT-PCR and western blotting evaluation of spinal cord TNF-a, IL-1 $\beta$ and IL-6 expression. I Immunofluorescence staining to detect the expression of the microglial activation marker OX42. J, K TUNEL staining to detect spinal cord apoptosis. L, M Western blotting to detect spinal cord apoptosis related protein expression 


\section{Reference}

1. Rong Y, Ji C, Wang Z, Ge X, Wang J, Ye W, Tang P, Jiang D, Fan J, Yin G, Liu

W, Cai W. Small extracellular vesicles encapsulating CCL2 from activated astrocytes induce microglial activation and neuronal apoptosis after traumatic spinal cord injury. J Neuroinflamm. 2021;18:196.

\section{Publisher's Note}

Springer Nature remains neutral with regard to jurisdictional claims in published maps and institutional affiliations. 